\title{
Phytoprotection
}

\section{Effect of plant age, leaf age and leaf position on infection of carrot leaves by Cercospora carotae}

\section{A. Van Delden et O. Carisse}

Volume 74, numéro 2, 1993

URI : https://id.erudit.org/iderudit/706038ar

DOI : https://doi.org/10.7202/706038ar

Aller au sommaire du numéro

Éditeur(s)

Société de protection des plantes du Québec (SPPQ)l

ISSN

0031-9511 (imprimé)

1710-1603 (numérique)

Découvrir la revue

Citer cet article

Van Delden, A. \& Carisse, O. (1993). Effect of plant age, leaf age and leaf position on infection of carrot leaves by Cercospora carotae. Phytoprotection, 74(2),

75-87. https://doi.org/10.7202/706038ar
Résumé de l'article

On a évalué en serre l'influence de l'âge des plants, des feuilles et de la position des feuilles de carotte (Daucus carota var. sativa) sur le niveau d'infection par le Cercospora carotae. Le niveau d'infection a été estimé en comptant le nombre de lésions $\mathrm{cm}^{-2}$ de surface foliaire et en mesurant la période d'incubation. Le niveau d'infection a diminué au fur et à mesure que l'âge des plants augmentait de 39 à $60 \mathrm{j}$, puis est resté faible chez les plants âgés de 60 à 71 j. La période d'incubation a augmenté de 9 à 16,6 j avec l'âge des plants. Le niveau d'infection a diminué avec l'augmentation de l'âge des feuilles de 1 à 36 j, toutefois la variation entre les feuilles était grande. La période d'incubation a augmenté de 9 à 18,3 j avec l'âge des feuilles, quoique certaines lésions sont apparues tardivement. Le niveau d'infection n'a pas varié en fonction de la position des feuilles sur des plants de 10 et 13 semaines. Toutes les feuilles, à l'exception des deux plus jeunes, furent représentatives de l'infection surtout le plant. L'influence de la position des feuilles sur la période d'incubation fut différente pour les plants de 10 et de 13 semaines et pour les deux répétitions. Des plants de moins de $60 \mathrm{j}$ au stade sept à huit feuilles devraient être utilisés lors d'études sur le développement initial de la brûlure cercosporéenne de la carotte. 


\title{
Effect of plant age, leaf age and leaf position on infection of carrot leaves by Cercospora carotae
}

\author{
Arnout van Delden ${ }^{1}$ and Odile Carisse ${ }^{2}$
}

Received 1992-10-29; accepted 1993-07-23

A greenhouse study was conducted to determine the effects of plant age, leaf age and leaf position on infection of carrot (Daucus carota var. sativa) by Cercospora carotae. Infection was quantified as the number of lesions $\mathrm{cm}^{-2}$ of leaf surface and the length of incubation period. The relative number of lesions decreased linearly with increasing plant age from 39- to 60-d-old plants, and remained low from 60- to 71-d-old plants. The incubation period increased from 9.0 to $16.6 \mathrm{~d}$, with increasing plant age. Relative number of lesions decreased with increasing leaf age from 1 to $36 \mathrm{~d}$, but the variation among leaves was high. The incubation period increased from 9.0 to $18.3 \mathrm{~d}$ with increasing leaf age, but lesions on a few young leaves appeared relatively late. Generally, differences in relative number of lesions for leaves on different positions for 10- and 13-wk-old plants were not significant. Infection on all leaves except the two youngest was representative of infection on whole plant. Effect of leaf position on incubation period was different for the 10- and 13wk-old plants and for the two trials. Plants younger than $60 \mathrm{~d}$ old, in the sevento eight-leaf stages should be used for experiments on the initial development of Cercospora blight of carrots.

van Delden, A., and O. Carisse. 1993. Effet de l'âge des plants, des feuilles, et de la position des feuilles de carotte sur l'infection par le Cercospora carotae. PHYTOPROTECTION 74: 75-87.

On a évalué en serre l'influence de l'âge des plants, des feuilles et de la position des feuilles de carotte (Daucus carota var. sativa) sur le niveau d'infection par le Cercospora carotae. Le niveau d'infection a été estimé en comptant le nombre de lésions $\mathrm{cm}^{-2}$ de surface foliaire et en mesurant la période $\mathrm{d}^{\prime} \mathrm{incu}$ bation. Le niveau d'infection a diminué au fur et à mesure que l'âge des plants augmentait de 39 à 60 j, puis est resté faible chez les plants âgés de 60 à 71 j. La période d'incubation a augmenté de 9 à 16,6 j avec l'âge des plants. Le niveau d'infection a diminué avec l'augmentation de l'âge des feuilles de 1 à $36 \mathrm{j}$, toutefois la variation entre les feuilles était grande. La période d'incubation a augmenté de 9 à 18,3 j avec l'âge des feuilles, quoique certaines lésions sont apparues tardivement. Le niveau d'infection n'a pas varié en fonction de la position des feuilles sur des plants de 10 et 13 semaines. Toutes les feuilles, à l'exception des deux plus jeunes, furent représentatives de l'infection sur tout le plant. L'influence de la position des feuilles sur la période d'incubation fut différente pour les plants de 10 et de 13 semaines et pour les deux répétitions. Des plants de moins de $60 \mathrm{j}$ au stade sept à huit feuilles devraient être utilisés lors d'études sur le développement initial de la brûlure cercosporéenne de la carotte.

1. Student at Wageningen Agricultural University, Department of Plant Pathology, POB 8025, 6700 EE Wageningen, The Netherlands.

2. Agriculture Canada Research Station, 430 Gouin blvd., Saint-Jean-sur-Richelieu, Québec, Canada J3B 3E6. Author to whom correspondence should be addressed. 


\section{INTRODUCTION}

Carrot leaf blight, caused by Cercospora carotae (Pass.) Solheim, a foliar disease of carrot (Daucus carota L. var. sativa Hoffm.), is found in almost all commercial carrot fields in the southwestern part of Québec, Canada (Arcelin and Kushalappa 1991). Diseased leaves and petioles break off easily during mechanical harvesting, resulting in unharvested roots. In commercial carrot fields, the disease is controlled with fungicides applied at 7- to 10-d intervals (CPVQ 1987). Recently, the effects of leaf wetness duration and temperature, relative humidity and temperature, and interrupted leaf wetness periods on infection of carrots by $C$. carotae have been reported (Carisse and Kushalappa $1990,1992)$. In these studies, the infection by $C$. carotae was quantified only on the second and third leaves of 5-wk-old carrots in the six-leaf stage (Carisse 1992; Carisse and Kushalappa 1990, 1992). Hooker (1944) inoculated carrots in the four-leaf stage and found that upper carrot leaves are more susceptible to $C$. carotae than lower leaves. Unfortunately, he used a disease index and did not precisely quantify the disease. Information from these and other studies (Carisse 1992) on the effect of the physical environment on Cercospora blight development could be used to manage the disease, to develop a disease forecasting system and if coupled with a carrot growth model, to simulate the development of the disease on all leaves of a plant. However, it is necessary to verify if seedlings are good predictors of the response of adult plants.

Differences in infection of leaves can be attributed to differences in microclimate within the plant canopy or to differences in leaf susceptibility (Populer 1978). The effect of weather on infection is known (Carisse and Kushalappa 1990, 1992) and microclimate can be easily measured in the field. However, the effect of plant age, leaf age and leaf position on infection need to be studied for Cercospora blight of carrot.

The objectives of this work were: 1) to study the effect of plant age, leaf age and leaf position on carrot infection by $C$. carotae; 2 ) to determine which leaves are good estimators of the average number of lesions of the whole carrot plant; 3 ) to determine if leaves on different positions on the plant could be grouped according to their susceptibility.

\section{MATERIALS AND METHODS}

\section{Plant production}

Carrot plants (cv. Dagger) were seeded in $21-\mathrm{cm}$-diam pots, containing $6 \mathrm{~L}$ of organic soil $(44 \%$ o.m.). The cultivar Dagger, a late-sown cultivar, was used in this experiment because it was used for previous infection studies (Carisse and Kushalappa 1990, 1992). Fertilizers were applied in a single dose and incorporated in the soil before seeding at a rate of 2.5 g 34-0-0 $\left(\mathrm{NH}_{4} \mathrm{NO}_{3}\right), 7.5 \mathrm{~g} \mathrm{0-46-0}\left(\mathrm{P}_{2} \mathrm{O}_{5}\right), 9.6$ g 0-0-62 (KCl), $1.5 \mathrm{~g} \mathrm{CuSO}_{4}$ and $5.6 \mathrm{~g}$ $\mathrm{MgSO}_{4}$ for $27.5 \mathrm{~kg}$ of soil. The lower $2 \mathrm{~cm}$ of the pots were filled with gravel to improve drainage.

The plants were grown in a greenhouse, maintained at $22 \pm 2{ }^{\circ} \mathrm{C}$ (day) and $15 \pm 2^{\circ} \mathrm{C}$ (night), $\mathrm{RH} \leq 80 \pm 5 \%$ and $16 \mathrm{~h}$ of light $\mathrm{d}^{-1}$. During less favorable natural light conditions, supplementary lighting was supplied by high-pressure sodium (HPS) lamps (Lumiponic, S.H.P.-S.O. 400 $\left.\mathrm{W}, 70 \mu \mathrm{mol} \cdot \mathrm{m}^{-2} \cdot \mathrm{s}^{-1}\right)$ to extend the photoperiod to $16 \mathrm{~h}$.

For the first trial, insecticides were applied four times to control aphids and mites: Pirimor 50 WP (pirimicarb, $2.09 \mathrm{~g}$ a.i. $\left.L^{-1}\right)$ against aphids, Trounce $L(0.2 \%$ pyrethrins and $20 \%$ potassium salts, 10.1 $\mathrm{g}$ a.i. $\left.\mathrm{L}^{-1}\right)$ against aphids and applied twice; and Safers $L(50.5 \%$ potassium salts from

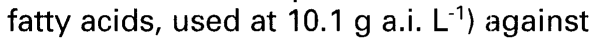
aphids and mites. The last application was done $12 \mathrm{~d}$ prior to the inoculation. For each application, $4.54 \mathrm{~L}$ of solution was used.

\section{Inoculum production}

An isolate of C. carotae was obtained from naturally infected carrot leaves collected in 1987 at the Agriculture Canada Experimental farm in Sainte-Clotilde, Québec (Carisse and Kushalappa 1990). A monospore culture was maintained on carrot leaf infusion agar (CLA) at $26^{\circ} \mathrm{C}$ under a 12-h photoperiod. A fresh culture was obtained by reisolating $C$. carotae 
from infected carrot leaves (Carisse and Kushalappa 1989). The fresh culture was maintained at $20-24^{\circ} \mathrm{C}$ under 8- to $12-\mathrm{h}$ light $d^{-1}$. After $1 \mathrm{wk}$, several CLA plates were inoculated with a spore suspension made from the fresh culture in order to increase the quantity of spores. The plates were maintained at $20-24^{\circ} \mathrm{C}$ and 8- to $12-\mathrm{h}$ photoperiod, and after $7 \mathrm{~d}$ transferred to $26^{\circ} \mathrm{C}$ and 12 -h photoperiod.

Inoculum was prepared by pouring a solution of $0.01 \%$ Tween 80 in distilled water on 12-d-old cultures (Carisse and Kushalappa 1990). The cultures were gently rubbed with a labspoon to dislodge the spores. The concentration of the conidial suspension was adjusted to $10^{4}$ conidia $\mathrm{mL}^{-1}$ using a haemacytometer.

\section{Inoculation}

The carrot leaves were inoculated on both surfaces until run off, using an artist air brush (Paashe, pump model 0211-V45NG8CX, brush model $\mathrm{H}$ ) operated at 100 $\mathrm{kPa}$ of air pressure. Immediately after inoculation, the plants were enclosed in plastic bags and kept in the same greenhouse. After $72 \mathrm{~h}$, the plastic bags were untightened, and after $96 \mathrm{~h}$ removed, to avoid wilting of the leaves. The spore deposition was evaluated during the inoculation, by spraying three water-agar plates every 50 leaves, starting at the beginning of the inoculation. The plates were maintained at $8^{\circ} \mathrm{C}$, until the spores were observed. On each plate, the number of spores within four circles of 12$\mathrm{mm}$ diam was counted. Percent spore germination was estimated by spraying three water-agar plates at the beginning, three at the middle and three at the end of the inoculation. After spraying, the plates were maintained at $24^{\circ} \mathrm{C}$, for $3 \mathrm{~h}$ in the first trial and for $6 \mathrm{~h}$ in the second trial and then stored at $8^{\circ} \mathrm{C}$. Since the spores were not germinating well, the plates were transferred to $17^{\circ} \mathrm{C}$ for $1 \mathrm{~d}$ after which the spore germination was estimated. A total of 50 spores per agar plate was observed from which the percent spore germination was calculated.

\section{Treatments}

The effects of plant age, leaf age and leaf position were examined in two series of experiments (Table 1). Both experiments were arranged as a completely randomized design, and conducted twice. For experiment $I$, the size of experimental units varied from 4 to 7 plants per plant age level, and from 1 to 5 leaves per leaf age level. For experiment II, the size of experimental units varied from 1 to 10 leaves per leaf position.

\section{Experiment l: Effect of plant age and leaf age on infection}

Leaves 4 and 5 were selected to study the effect of plant age. Seven carrot seeds were sown twice a week during the $10 \mathrm{wk}$ preceding the day of inoculation. The fourth and the fifth true leaves from the bottom were tagged, at the time of unfolding. A leaf was defined as unfolded (spore susceptible) when its leaflet blades were separated by an angle greater than

Table 1. Plant age, leaf age and leaf positions used in both experiments I and II

\begin{tabular}{ccccc}
\hline $\begin{array}{c}\text { Experiment } \\
\text { number }\end{array}$ & $\begin{array}{c}\text { Trial } \\
\text { number }\end{array}$ & $\begin{array}{c}\text { Plant age } \\
\text { (exp. I:d) } \\
\text { (exp. Il:wk) }\end{array}$ & $\begin{array}{c}\text { Position of } \\
\text { inoculated } \\
\text { leaves }\end{array}$ & $\begin{array}{c}\text { Leaf age } \\
\text { (d) }\end{array}$ \\
\hline 1 & 1 & $39,43,46,53,56,60,68,71$ & 4 & $1-36$ \\
& 2 & $39,43,46,53,56,60,67,71$ & 5 & $1-30$ \\
II & 1 & 10 & 5 & $1-35$ \\
& 2 & 13 & $2-10$ & $1-29$ \\
& 2 & 10 & $1-10$ & \\
& & 13 & $3-10$ & \\
\hline
\end{tabular}

a Leaf age was calculated from the day of unfolding to the day of inoculation. 
$90^{\circ}$. The plants were examined almost every day. The plant age was calculated from the day of sowing to the day of inoculation, and the age of the leaves from the day of unfolding to the day of inoculation. Leaves unfolded on the day of inoculation were defined as 1-d-old leaves. The age of leaves from the same position on plants of the same age was different (up to $11 \mathrm{~d}$ ) due to differences in the growth rate of individual plants. The plants were selected at random for inoculation, and all tagged leaves were inoculated.

\section{Experiment II: Effect of leaf position on infection}

Carrot seeds were sown 10 and 13 wk prior to the day of inoculation. On each sowing date 13 or 15 seeds were sown, of which 10 healthy plants were later selected for inoculation. All the leaves were numbered from 1 to $n$, where leaf 1 was the first leaf from the bottom, leaf 2 the second one, etc. Dead or senescent leaves were taken into account. The plants were selected at random for inoculation, and all healthy leaves were inoculated.

\section{Estimation of infection}

Infection was quantified by counting the number of lesions on each inoculated leaf. The lesions were counted at 2-d intervals. However, a 3-d interval was taken $18 \mathrm{~d}$ after inoculation, because no new lesions were expected. The counts started $10 \mathrm{~d}$ after inoculation (first visible lesions) and continued until the number of lesions on each inoculated leaves stopped to increase (all lesions had appeared) (Carisse and Kushalappa 1990). The area of each leaf was measured using a leaf area meter on the day following the last counting (Model LI-3100, Li-cor Inc., Lincoln, Nebraska). The data were transformed into number of lesions $\mathrm{cm}^{-2}$ of leaf surface, by dividing the highest number of lesions observed by its leaf area. Within each experiment and trial the relative number of lesions $\mathrm{cm}^{-2}$ of leaf surface was calculated by dividing the observed number of lesions $\mathrm{cm}^{-2}$ by the highest number of lesions $\mathrm{cm}^{-2}$ so that the data ranged from 0 to 1 .

The incubation period was defined as the time in $d$ from inoculation to the appearance of the first lesions with a necrotic centre or chlorosed halo. The incubation period was recorded by observing the plants every day until the last day of lesion counting.

\section{Data analysis}

Within each treatment, the homogeneity of variances of the two trials was tested (F-test) to determine whether the data from the two trials could be pooled. Data from each experiment were subjected to analysis of variance (ANOVA), to determine if differences in infection could be attributed to plant age, leaf age or leaf position. The two trials were analyzed separately when the data could not be pooled. Differences among treatment means were detected using the WallerDuncan K-ratio $T$ test $(K-$ ratio $=100)$. The data for the leaf position were subjected to cluster analyses to determine if leaves from different positions could be grouped together according to the level of susceptibility to $C$. carotae. All analyses were conducted using SAS/STAT software for IBM-PC (SAS Institute Inc. 1987).

\section{RESULTS}

Percentage of spore germination for the first and second trial was 96.4 and $88.2 \%$, respectively. The spore deposition for the first trial (2.74 spores $\mathrm{cm}^{-2}$ ) was lower than for the second trial (4.84 spores $\mathrm{cm}^{-2}$ ). The data of the two trials, when expressed as the number of lesions $\mathrm{cm}^{-2}$ and the incubation period in $\mathrm{d}$ could not be pooled $(P \leq 0.05)$. However, when the number of lesions $\mathrm{cm}^{-2}$ was expressed as relative number of lesions, pooling of the data was possible $(P>0.05)$, except for the data of experiment I on leaf $4(P \leq 0.001)$. Furthermore, after transforming the relative number of lesions $\mathrm{cm}^{-2}$ using arcsin square root of $Y$, pooling of the data was possible $(P>0.05$ and $0.01 \leq P$ $\leq 0.025$ for plant age and leaf age, respectively).

\section{Effect of plant age and leaf age on infection}

The relative number of lesions varied significantly with plant and leaf age $(P=$ 0.0001 ). It decreased linearly with plant age until the plants were $60-\mathrm{d}$ old and then remained low (Fig. 1). On 39- to 


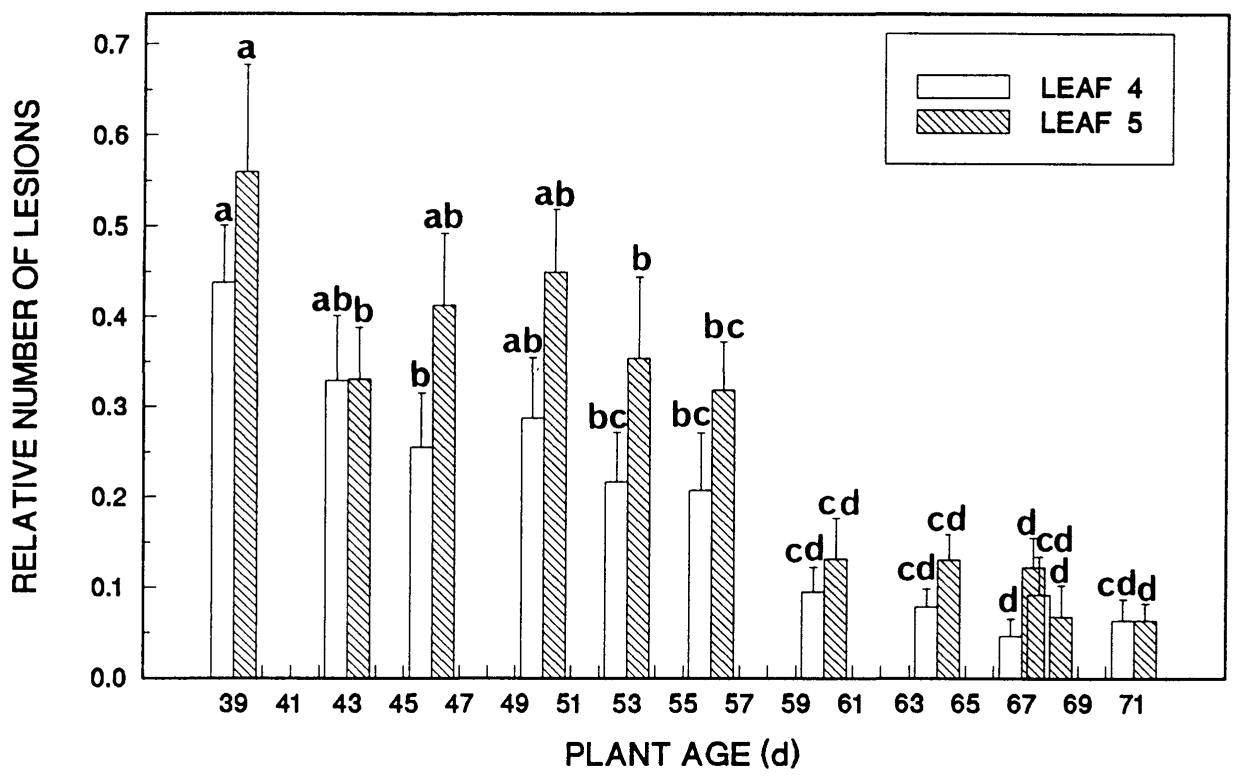

Figure 1. Effect of carrot plant age on infection of leaves 4 and 5 by Cercospora carotae. Leaves were numbered from the bottom of the plant. For each bar, the data represents an average of the two trials (6 to 14 leaves). Lines over bars are the standard error of the means. The same letters over bars indicate that the data are not significantly different according to the WallerDuncan K-ratio $T$ test $(K-$ ratio $=100)$. Only bars of the same leaf position should be compared.

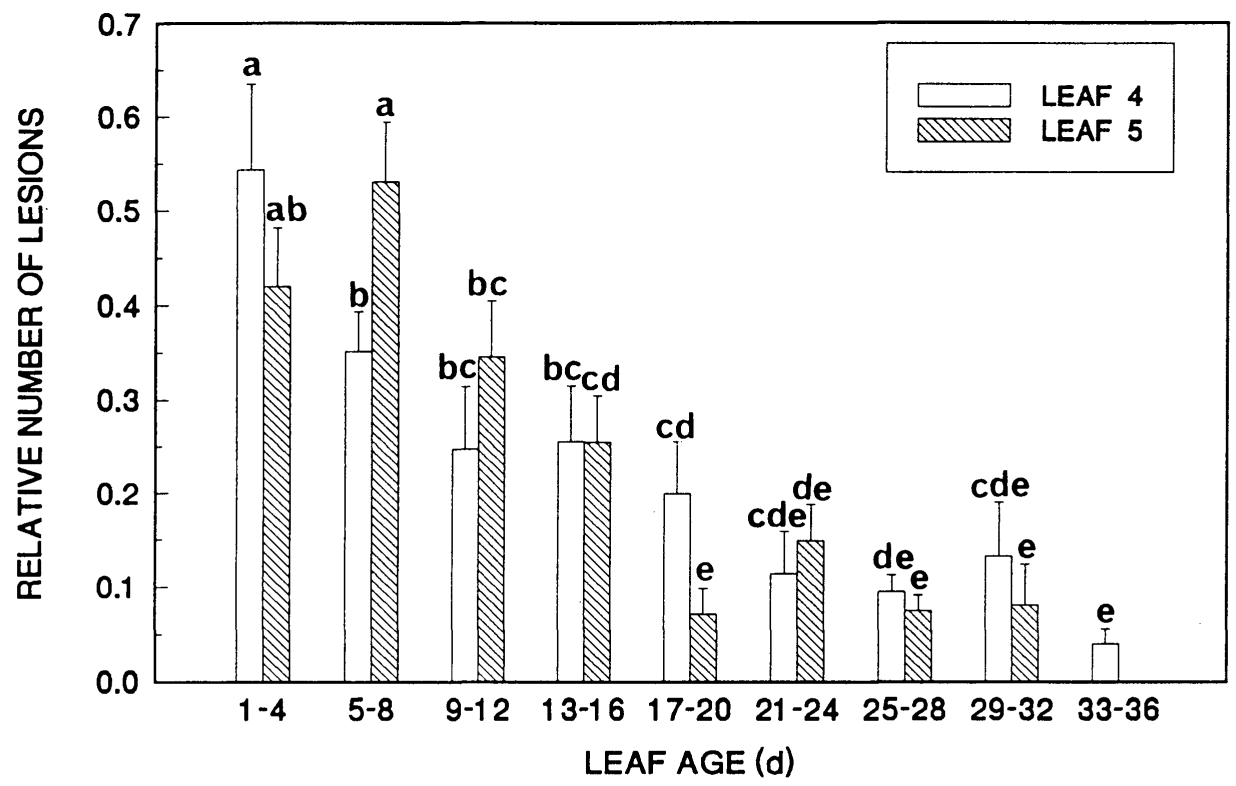

Figure 2. Effect of carrot leaf age on infection of leaves 4 and 5 by Cercospora carotae. Leaves were numbered from the bottom of the plant. Leaves unfolded within a period of $4 \mathrm{~d}$ were placed in the same age group. For each bar, the data represents an average of the two trials ( 1 to 10 leaves per trial). Lines over bars are the standard error of the means. The same letters over bars indicate that the data are not significantly different according to the Waller-Duncan K-ratio T test (K-ratio $=100)$. Only bars within the same leaf position should be compared. 
50-d-old plants (Fig. 1), the relative number of lesions was significantly $(P \leq$ 0.05 ) higher than on 60- to 71-d-old plants, thereby indicating that the leaves 4 and 5 became less susceptible when the plant age reached $60 \mathrm{~d}$. The infection decreased with increasing leaf age (Table 2), but the variation among the leaves was very high. Only leaves with extreme values were significantly different $(P \leq 0.05)$. The leaves were grouped according to their age in 4-d groups. Leaves which unfolded within a period of $4 \mathrm{~d}$ were assigned to the same age group (Fig. 2). Based on this grouping, 1- to 12-d-old leaves had a significantly $(P \leq 0.05)$ higher relative number of lesions than 25- to 36-d-old leaves and infection decreased from 1 to 36-d-old leaves. In general, the relative number of lesions on leaf 4 was not significantly different from leaf 5 .

Almost all lesions appeared later in the second trial than in the first one, even though some lesions were seen very early in the second trial (Fig. 3). Plant age had a significant effect on incubation period $(P \leq 0.0011)$, except for leaf 5 of the first

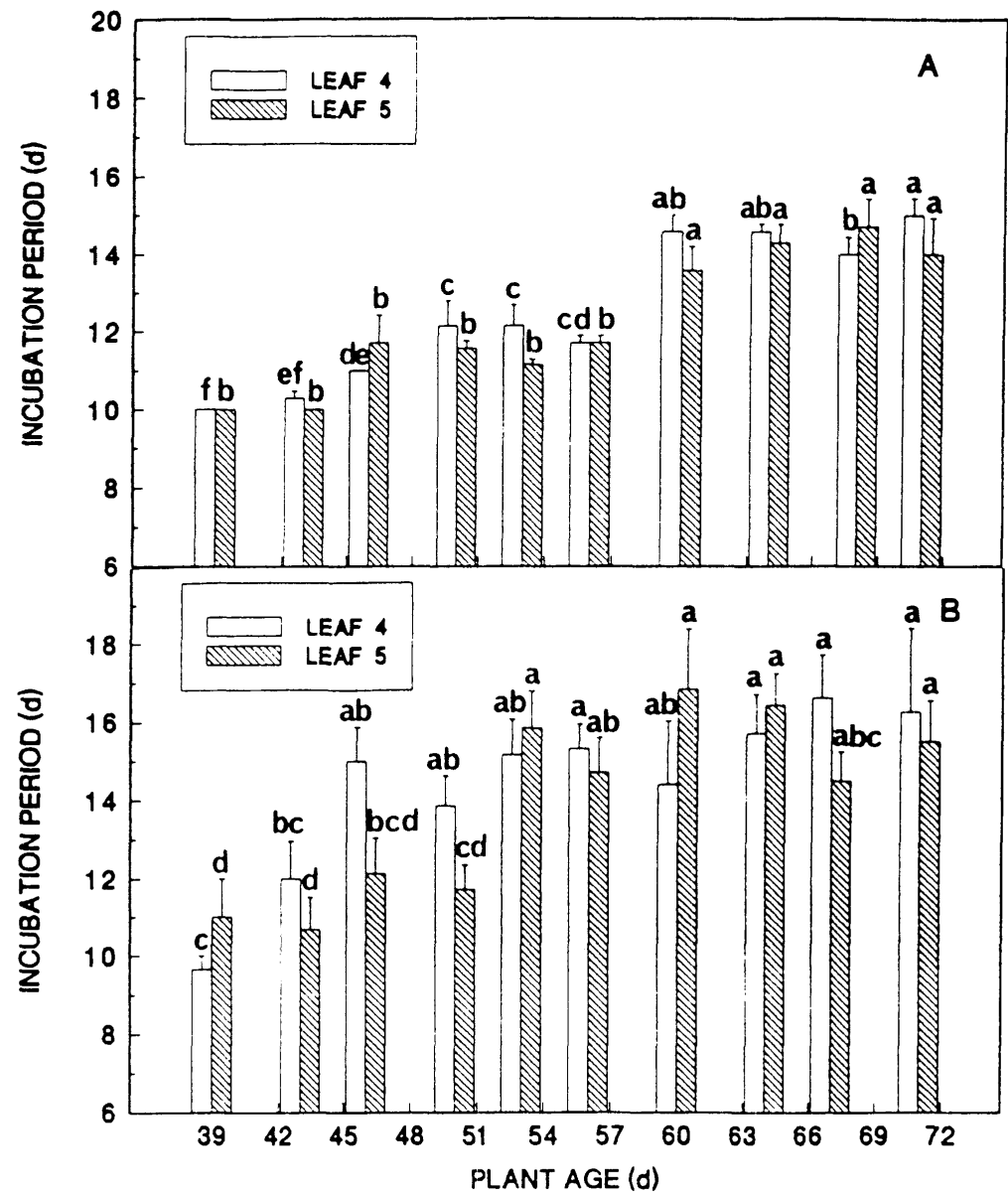

Figure 3. Effect of carrot plant age on incubation period of Cercospora carotae on leaves 4 and 5 , for trial 1 (A) and trial 2 (B). Leaves were numbered from the bottom of the plant. Lines over bars are the standard error of the means. The same letters over bars indicate that the data are not significantly different according to the Waller-Duncan K-ratio T test (K-ratio $=100)$. Only bars within one leaf position and trial should be compared. 
Table 2. Effect of carrot leaf age on infection of leaves 4 and 5 by Cercospora carotae

\begin{tabular}{|c|c|c|}
\hline \multirow{2}{*}{$\begin{array}{l}\text { Leaf } \\
\text { age } \\
\text { (d) }\end{array}$} & \multicolumn{2}{|c|}{ Relative number of lesions ${ }^{a}$} \\
\hline & Leaf 4 & Leaf 5 \\
\hline 1 & $0.31 \mathrm{bcdef}^{\mathrm{b}}$ & 0.29 abcdefg \\
\hline 2 & $0.54 \mathrm{ab}$ & 0.48 abcde \\
\hline 3 & 0.33 bcdef & 0.38 abcdefg \\
\hline 4 & $0.77 \mathrm{a}$ & $0.53 a b c$ \\
\hline 5 & 0.29 bcdef & \\
\hline 6 & $0.53 a b c$ & $0.65 a$ \\
\hline 7 & 0.38 bcde & 0.44 abcdef \\
\hline 8 & 0.23 bcdef & $0.49 \mathrm{abcd}$ \\
\hline 9 & 0.06 def & $0.57 a b$ \\
\hline 10 & 0.27 bcdef & 0.25 bcdefg \\
\hline 11 & 0.23 bcdef & 0.28 abcdefg \\
\hline 12 & 0.35 bcdef & 0.37 abcdefg \\
\hline 13 & $0.42 \mathrm{abcd}$ & \\
\hline 14 & 0.31 bcdef & 0.30 abcdefg \\
\hline 15 & 0.10 def & 0.19 bcdefg \\
\hline 16 & 0.05 ef & 0.16 cdefg \\
\hline 17 & 0.22 bcdef & $0.01 \mathrm{~g}$ \\
\hline 18 & 0.10 def & $0.04 \mathrm{~g}$ \\
\hline 19 & 0.29 bcdef & 0.15 defg \\
\hline 20 & 0.03 ef & $0.07 \mathrm{fg}$ \\
\hline 21 & 0.12 def & 0.24 bcdefg \\
\hline 22 & 0.18 bcdef & 0.11 defg \\
\hline 23 & 0.02 ef & $0.11 \mathrm{efg}$ \\
\hline \multicolumn{3}{|l|}{24} \\
\hline 25 & 0.06 def & $0.07 \mathrm{fg}$ \\
\hline 26 & 0.12 def & $0.07 \mathrm{fg}$ \\
\hline 27 & 0.17 cdef & $0.06 \mathrm{fg}$ \\
\hline 28 & & $0.09 \mathrm{fg}$ \\
\hline 29 & 0.18 bcdef & $0.10 \mathrm{fg}$ \\
\hline 30 & 0.03 ef & $0.01 \mathrm{~g}$ \\
\hline 31 & $0.07 \mathrm{def}$ & \\
\hline 32 & 0.10 def & \\
\hline 33 & 0.03 ef & \\
\hline 34 & $0.01 \mathrm{f}$ & \\
\hline 35 & 0.08 def & \\
\hline 36 & $0.11 \mathrm{def}$ & \\
\hline
\end{tabular}

a For each trial and leaf position the relative number of lesions $\mathrm{cm}^{-2}$ was obtained by dividing the observed number of lesions $\mathrm{cm}^{-2}$ by the maximum value. The maximum observed values for leaf 4 , trial 1 and 2 , were 2.73 and 1.67 , respectively. The maximum observed values for leaf 5 , trial 1 and 2, were 2.78 and 0.69 respectively. Depending on leaf age the number of leaves observed varied from one to eight.

b Values in a column followed by the same letter are not significantly different according to the Waller-Duncan K-ratio T-test $(\mathrm{K}$-ratio $=100)$. 
trial, where a significant effect of the replicates was found $(P=0.0233)$. The incubation period increased from 9.7 to $16.8 \mathrm{~d}$, with increasing plant age. In the first trial, lesions appeared later $(P \leq 0.05)$ on 60- to 71-d-old plants than on 39- to 56 -d-old plants. Leaf age had a significant effect on the incubation period $(P \leq 0.01)$. Lesions appeared later with increasing leaf age (Table 3 ), except on a few young leaves where the lesions also appeared late. The leaves were grouped according to their age in 4-d groups (leaves unfolded within a period of $4 \mathrm{~d}$ were in the same age group). Based on that grouping, lesions appeared earlier on 1- to 12-d-old leaves than on 21- to 36-d-old leaves (Fig. 4). On leaf 5 , the incubation period was long for 17- to 20-d-old leaves. This was explained by the rather long incubation periods recorded in two replicates.

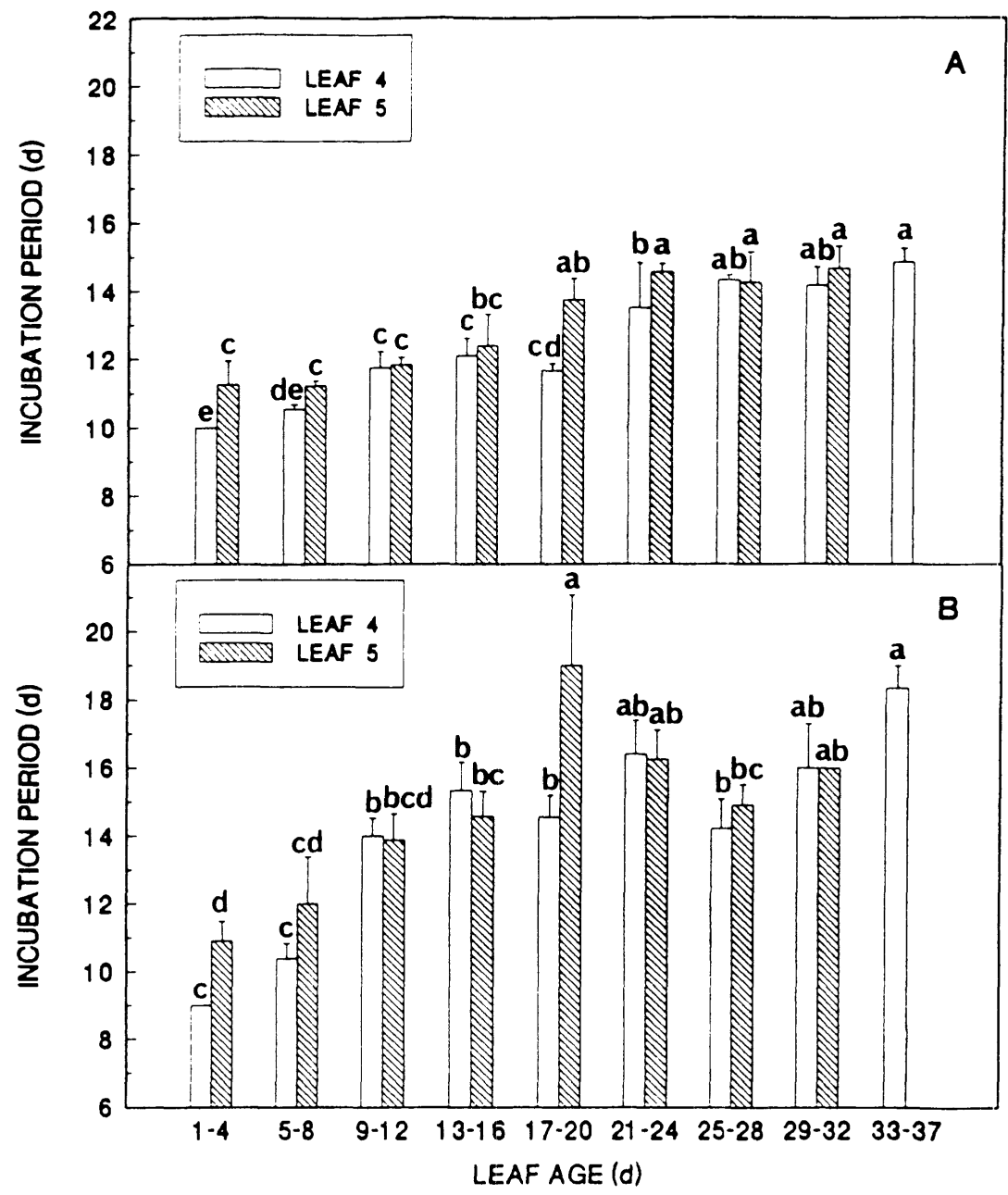

Figure 4. Effect of carrot leaf age on incubation period of Cercospora carotae on leaves 4 and 5, for trial 1 (A) and trial 2 (B). Leaves were numbered from the bottom of the plant. Leaves unfolded within a period of $4 \mathrm{~d}$ were placed in the same age group. Lines over bars are the standard error of the means. Same letters over bars mean data are not significantly different according to the Waller-Duncan K-ratio $T$ test $(K$-ratio $=100)$. Only bars within one leaf position and trial should be compared. 
Table 3. Effect of carrot leaf age on incubation period of Cercospora carotae on leaves 4 and 5

\begin{tabular}{|c|c|c|c|c|}
\hline \multirow{3}{*}{$\begin{array}{l}\text { Leaf } \\
\text { age } \\
\text { (d) }\end{array}$} & \multicolumn{4}{|c|}{ Incubation period $(d)^{a}$} \\
\hline & \multicolumn{2}{|c|}{ Leaf 4} & \multicolumn{2}{|c|}{ Leaf 5} \\
\hline & Trial 1 & Trial 2 & Trial 1 & Trial 2 \\
\hline 1 & $10.0 \mathrm{~g}^{\mathrm{b}}$ & & 11.6 efg & $12.0 \mathrm{~cd}$ \\
\hline 2 & $10.0 \mathrm{~g}$ & & $10.7 \mathrm{~g}$ & $10.3 \mathrm{~d}$ \\
\hline 3 & & $9.0 \mathrm{~d}$ & & $13.0 \mathrm{bcd}$ \\
\hline 4 & $10.0 \mathrm{~g}$ & $9.0 \mathrm{~d}$ & & $10.3 \mathrm{~d}$ \\
\hline 5 & $10.0 \mathrm{~g}$ & $10.6 \mathrm{bcd}$ & & \\
\hline 6 & $10.3 \mathrm{fg}$ & $9.0 \mathrm{~d}$ & $11.0 \mathrm{~g}$ & $10.7 \mathrm{~d}$ \\
\hline 7 & $10.8 \mathrm{efg}$ & $11.0 \mathrm{bcd}$ & 11.7 defg & $11.0 \mathrm{~d}$ \\
\hline 8 & $11.0 \mathrm{efg}$ & $10.0 \mathrm{~cd}$ & $11.0 \mathrm{~g}$ & $17.0 \mathrm{abc}$ \\
\hline 9 & $15.5 \mathrm{abcd}$ & $11.5 \mathrm{fg}$ & & \\
\hline 10 & $11.0 \mathrm{efg}$ & $12.5 \mathrm{abcd}$ & 11.7 defg & $13.3 \mathrm{bcd}$ \\
\hline 11 & $11.0 \mathrm{efg}$ & $14.5 \mathrm{abcd}$ & 11.7 cdefg & $14.8 \mathrm{abcd}$ \\
\hline 12 & 12.5 cdef & $13.0 \mathrm{abcd}$ & 12.7 defg & $13.0 \mathrm{bcd}$ \\
\hline 13 & $12.5 \mathrm{cdef}$ & $13.0 \mathrm{abcd}$ & $11.5 \mathrm{fg}$ & $16.0 \mathrm{abcd}$ \\
\hline 14 & $11.8 \mathrm{efg}$ & $13.0 \mathrm{abcd}$ & $11.5 \mathrm{fg}$ & $14.2 \mathrm{bcd}$ \\
\hline 15 & 12.0 defg & $15.8 \mathrm{abc}$ & $16.0 \mathrm{a}$ & $14.8 \mathrm{abcd}$ \\
\hline 16 & & $18.0 \mathrm{a}$ & & $13.0 \mathrm{bcd}$ \\
\hline 17 & $11.7 \mathrm{efg}$ & $13.0 \mathrm{abcd}$ & & $20.5 \mathrm{a}$ \\
\hline 18 & 12.0 defg & $15.3 \mathrm{abcd}$ & 14.0 abcdef & \\
\hline 19 & $11.5 \mathrm{efg}$ & $15.0 \mathrm{abcd}$ & 13.0 bcdefg & $16.0 \mathrm{abcd}$ \\
\hline 20 & & $14.0 \mathrm{abcd}$ & $15.0 \mathrm{abc}$ & \\
\hline 21 & $11.0 \mathrm{efg}$ & $16.8 a b$ & $15.5 \mathrm{ab}$ & $14.3 \mathrm{bcd}$ \\
\hline 22 & $14.3 \mathrm{abc}$ & & 14.3 abcde & $17.0 \mathrm{abc}$ \\
\hline 23 & & $15.0 \mathrm{abcd}$ & $14.3 \mathrm{abcd}$ & $18.0 a b$ \\
\hline \multicolumn{5}{|l|}{24} \\
\hline 25 & $14.3 \mathrm{abcd}$ & $13.0 \mathrm{abcd}$ & 14.0 abcdef & $16.0 \mathrm{abcd}$ \\
\hline 26 & $14.4 \mathrm{abc}$ & $14.0 \mathrm{abcd}$ & $16.5 \mathrm{a}$ & $15.0 \mathrm{abcd}$ \\
\hline 27 & & $12.8 \mathrm{abcd}$ & $11.0 \mathrm{~g}$ & $13.0 \mathrm{bcd}$ \\
\hline 28 & $14.3 \mathrm{abc}$ & $18.0 \mathrm{a}$ & 14.0 abcdef & $15.0 \mathrm{abcd}$ \\
\hline 29 & $14.4 \mathrm{abc}$ & $14.5 \mathrm{abcd}$ & 14.0 abcdef & $16.0 \mathrm{abcd}$ \\
\hline 30 & & $15.0 \mathrm{abcd}$ & $16.0 \mathrm{a}$ & \\
\hline 31 & & $16.7 a b$ & & \\
\hline 32 & 13.0 bcde & $18.0 \mathrm{a}$ & & \\
\hline 33 & $15.0 \mathrm{ab}$ & $17.0 \mathrm{ab}$ & & \\
\hline 34 & 13.0 bcde & $19.0 \mathrm{a}$ & & \\
\hline 35 & $15.0 \mathrm{ab}$ & $19.0 \mathrm{a}$ & & \\
\hline 36 & $15.5 \mathrm{a}$ & & & \\
\hline
\end{tabular}

a Incubation period was defined as the time in $d$ from inoculation to the first appearance of lesions with a necrotic centre or chlorosed halo. Depending of leaf age, the number of leaves observed varied from one to five.

b Values in a column followed by the same letter are not significantly different according to the Waller-Duncan K-ratio T test $($ K-ratio $=100)$. 


\section{Effect of leaf position on infection}

Effect of leaf position on the relative number of lesions was different for 10 and 13-wk-old plants (Table 4). For 10wk-old plants, leaf position had a significant effect on the relative number of lesions $(P=0.0091)$. However, leaves 2 to 8 were not significantly different. The leaves were grouped as follows $\left(R^{2}=\right.$ 0.9423): $2,3,6,7$ and $8 ; 4$ and $5 ; 9 ; 10$. For 13-wk-old-plants, the model of the analysis of variance was not significant $(P=$ 0.6927 ), and no significant differences were found between the relative number of lesions with regard to different leaf positions (Table 4). On leaf 2, no lesion appeared but this was only based on one leaf. The leaves were grouped as follows $\left(R^{2}=0.9451\right): 2$ and $12 ; 3$ to $6 ; 7$ to 10 ; and 11. For both the 10- and 13-wk-old plants almost no lesions developed on the highest leaf, but this leaf was not completely unfolded at the time of inoculation.

To determine which leaves could give a good estimate for the average number of lesions on the whole plant, the relative number of lesions on a single leaf position was compared with the average of the whole plant (all leaf positions), for 10and 13-wk-old plants. No leaf position was significantly different $(P \leq 0.05)$ from the average value for the whole plant. The number of lesions $\mathrm{cm}^{-2}$ on leaves 4 and 5 (experiment 1 ) were compared with the number of lesions $\mathrm{cm}^{-2}$ on leaves from all different positions (experiment II) of 10 -wk-old plants within a trial to determine if leaves 4 and 5 could be good estimators of infection on other leaf positions. No significant differences were found between the number of lesions on leaves 4 and 5 and leaves from other leaf positions. Infection on leaves 4 and 5 was thus a good estimate of infection on all leaves of 10-wk-old plants.

The number of lesions $\mathrm{cm}^{-2}$ of $10-\mathrm{wk}$ old plants was compared to that of the 13-wk-old plants within a trial for all leaf positions to determine if a plant age effect could be found. For the first trial, only leaves 6 to 9 , and for the second trial, only leaves 8 and 9 for 10 -wk-old plants had a significantly $(P \leq 0.05)$ higher number of lesions $\mathrm{cm}^{-2}$ than the corresponding leaves on 13-wk-old plants.
The length of incubation period varied with the leaf position (Table 5), but a specific pattern was not observed. In general, lesions appeared 2 to 3 d later on 13- than on 10-wk-old plants. Leaf position had a significant effect $(P=0.0001)$ on incubation period in the first trial, but was not significant in the second trial. For the 10-wk-old plants, the shortest incubation period was observed on leaves 8 and 9. This incubation period was significantly different from that of leaves 4 to $6(P \leq 0.05)$. The same pattern was not observed for the 13-wk-old plants. In the second trial no significant differences in incubation period among the different leaf positions were observed.

\section{DISCUSSION}

In this study, the change in susceptibility of the leaves was better described by plant age than by leaf age. Two groups of plants were observed: 39 - to 56-d-old plants and 60-d-old and older plarits, the first group being more susceptible than the second one. Leaves older than $21 \mathrm{~d}$ were less susceptible than younger leaves. It was possible to group leaves from different positions on a plant according to their infection level. However, infection level among the leaf positions was only significantly different in particular situations. This indicates that grouping of the leaves according to the leaf position, for 10- and 13-wk-old plants is not necessary. Hooker (1944) found an effect of leaf position on infection of young plants, but the effect of the leaf position might depend on the age of the carrot plant. This might also explain the difference in infection between the 10- and 13-week-old plants. Thus, our results could not be extrapolated to younger plants.

The infection level on each leaf of 10 - and 13-wk old plants was not significantly different from the average infection level of the whole plant. However, to develop a good estimator of the infection of the whole plant, the infection level should be close to the average value and the leaves must be unfolded at the time of inoculation. This was not the case for the two youngest and the oldest leaves, and therefore they should not be used. 
Table 4. Effect of carrot leaf position on infection by Cercospora carotae

\begin{tabular}{|c|c|c|c|c|}
\hline \multirow[b]{2}{*}{$\begin{array}{l}\text { Leaf } \\
\text { position }\end{array}$} & \multicolumn{2}{|c|}{ 10-wk-old plants } & \multicolumn{2}{|c|}{ 13-wk-old plants } \\
\hline & $\begin{array}{c}\text { Relative number } \\
\text { of lesions }^{a}\end{array}$ & Cluster $^{b}$ & $\begin{array}{c}\text { Relative number } \\
\text { of lesions }\end{array}$ & Cluster \\
\hline 2 & $0.20 a b^{c}$ & 3 & 0 & 1 \\
\hline 3 & $0.17 \mathrm{abc}$ & 3 & $0.27 a$ & 3 \\
\hline 4 & $0.10 \mathrm{bc}$ & 2 & $0.29 \mathrm{a}$ & 3 \\
\hline 5 & $0.11 \mathrm{bc}$ & 2 & $0.24 \mathrm{a}$ & 3 \\
\hline 6 & $0.18 \mathrm{abc}$ & 3 & $0.22 \mathrm{a}$ & 3 \\
\hline 7 & $0.18 \mathrm{abc}$ & 3 & $0.14 \mathrm{a}$ & 2 \\
\hline 8 & $0.24 a b$ & 3 & $0.18 \mathrm{a}$ & 2 \\
\hline 9 & $0.30 \mathrm{a}$ & 4 & $0.17 \mathrm{a}$ & 2 \\
\hline 10 & $0.02 \mathrm{c}$ & 1 & $0.18 \mathrm{a}$ & 2 \\
\hline 11 & & & $0.33 \mathrm{a}$ & 4 \\
\hline 12 & & & $0.06 \mathrm{a}$ & 1 \\
\hline
\end{tabular}

a For each trial and leaf position the relative number of lesions $\mathrm{cm}^{-2}$ was obtained by dividing the observed number of lesions $\mathrm{cm}^{-2}$ by the maximum value. For the 10-wk-old plants, the maximum number of lesions $\mathrm{cm}^{-2}$ for the first and the second trial, was 1.65 and 0.74 , respectively. For the 13-wk-old plants, the maximum number of lesions $\mathrm{cm}^{-2}$ for the first and the second trial was 0.22 and 0.12 , respectively. Depending on leaf position the number of leaves observed varied from 5 to 20, except for leaf position one where only one leaf was observed.

b Leaf positions with the same value are in the same cluster (PROC CLUSTER METHOD=AVERAGE (unweighed pair groups).

c Pooled data of two trials, each trial had a maximum of 10 observations. Values in a column followed by the same letter are not significantly different according to the Waller-Duncan Kratio $\mathrm{T}$ test $(\mathrm{K}$-ratio $=100)$.

Table 5. Effect of carrot leaf position on incubation period of Cercospora carotae

\begin{tabular}{|c|c|c|c|c|}
\hline \multirow{3}{*}{$\begin{array}{l}\text { Leaf } \\
\text { position }\end{array}$} & \multicolumn{3}{|c|}{ Incubation period $(d)^{a}$} & \\
\hline & \multicolumn{2}{|c|}{ 10-wk-old plants } & \multicolumn{2}{|c|}{ 13-wk-old plants } \\
\hline & Trial 1 & Trial 2 & Trial 1 & Trial 2 \\
\hline 2 & $14.0 \mathrm{ab}^{\mathrm{b}}$ & $14.0 \mathrm{abc}$ & & \\
\hline 3 & $13.6 \mathrm{ab}$ & $14.2 \mathrm{abc}$ & $14.0 \mathrm{c}$ & $16.3 \mathrm{a}$ \\
\hline 4 & $15.0 \mathrm{a}$ & $16.3 \mathrm{a}$ & $15.2 \mathrm{abc}$ & $17.5 \mathrm{a}$ \\
\hline 5 & $14.4 \mathrm{ab}$ & $16.4 \mathrm{a}$ & $15.6 \mathrm{abc}$ & $17.3 \mathrm{a}$ \\
\hline 6 & $14.0 \mathrm{ab}$ & $15.4 a b$ & $15.5 a b c$ & $17.4 \mathrm{a}$ \\
\hline 7 & $13.2 \mathrm{bc}$ & $14.0 \mathrm{abc}$ & 16.5 a & $16.8 \mathrm{a}$ \\
\hline 8 & $11.6 \mathrm{~d}$ & $12.1 \mathrm{bc}$ & $16.4 \mathrm{a}$ & $18.3 \mathrm{a}$ \\
\hline 9 & $11.9 \mathrm{~cd}$ & $11.1 \mathrm{c}$ & $16.3 \mathrm{ab}$ & $18.0 \mathrm{a}$ \\
\hline 10 & $14.3 a b$ & $14.7 a b$ & $15.3 \mathrm{abc}$ & $17.4 \mathrm{a}$ \\
\hline 11 & & & $14.4 \mathrm{bc}$ & $14.8 \mathrm{a}$ \\
\hline 12 & & & $15.0 \mathrm{abc}$ & $13.0 \mathrm{a}$ \\
\hline
\end{tabular}

a Incubation period was defined as the time in $d$ from inoculation to the first appearance of lesions with a necrotic centre or chlorosed halo around the lesion. Depending of leaf position the number of leaves observed varied from 1 to 10.

b Values in a column followed by the same letter are not significantly different according to the Waller-Duncan K-ratio T test $($ K-ratio $=100)$. 
In general, incubation period was shorter on young plants (56-d-old or less) and on young leaves (less than 16-d-old) and incubation period varied with leaf position, but a typical pattern could not be detected. Carisse (1992) studied the incubation period of $C$. carotae in the field on the cultivar Dagger. The second and third leaves of carrot plants at the six-leaf stage were inoculated. First lesions were observed 6 to $8 \mathrm{~d}$ after inoculation, new lesions appeared until the 10th to 14th $d$ and on the same leaf, lesions appeared within 3 to $5 \mathrm{~d}$. In our study, the first lesions appeared $4 \mathrm{~d}$ later than in the field study on plants in the five-leaf stage. This delay may be partially due to the definition of a lesion, since a lesion can be visible for 1 to $2 \mathrm{~d}$ before it develops a necrotic centre or a chlorosed halo.

The lower infection and the delay in lesion appearance in the second trial compared with the first trial cannot be explained by the spraying technique alone, since the deposition on water agar did not exactly correspond to the deposition on the leaves. The deposition of the spores on water agar in the second trial was higher than for the first trial. Additional lighting was probably not a limiting factor, since the intensity was high enough to open the stomata (Salisbury and Ross 1985) so that Cercospora spore penetration was not limited (Thomas 1943).

In summary, this study demonstrated that considering groups of leaves on different positions according to their susceptibility is not necessary, and all the unfolded and healthy leaves can be good estimators of the average number of lesions of the whole plant, when they are 10- to 13-wk-old. However, the results of the leaf position cannot be extrapolated to the younger plants as they may react differently. To describe Cercospora blight of carrot development in the field, two groups of plants can be considered, 39- to 56-d old plants and 60-d-old and older plants. Studies on the infection of C. carotae conducted to determine the timing of the first fungicide application should use leaves 4 to 6 of plants younger than $60 \mathrm{~d}$.

Changes in susceptibility of a host to a pathogen over time, expressed as plant age, leaf age and leaf position has been reported for several pathogens (Allen et al. 1983; Eisensmith et al. 1982; Gottwald 1985; Jennings et al. 1990). The pustule density of leek rust (Puccinia allii F. Rudolphi) increased from upper to lower leaves (Allium porrum cv. Musselburgh) in the non-tip portions of the leaves (Jennings et al. 1990). Resistance confined to the later-developed part of the plant, i.e. adult plant or mature plant resistance, has been widely reported for rusts (Puccinia spp.) and powdery mildew (Erysiphe spp.) diseases of wheat (Triticum aestivum L.) (Jones and Hayes 1971; Ohm and Shaner 1976; Parlevliet 1979; Pretorius et al. 1988). Very young plants are often poor predictors of the response of adult plants. When susceptibility changes extend over the whole life cycle of a plant, a common pattern is that susceptibility increases with increasing age of the plant parts (Fopuler 1978). An effect of leaf age on the leaf susceptibility similar to what we observed, was found for pecan leaves to infection by Cladosporium caryigenum (Ell. et Lang.). Leaf susceptibility was correlated with a high leaf trichome density and low palisade parenchyma phenolic content (Wetzstein and Sparks 1983). All chemical or mechanical changes over time may have contributed to change in susceptibility of the pecan leaves (Gottwald 1985).

Assuming that leaves in other positions on young plants behave like the leaves 4 and 5 , the disease will develop much slower on older than on younger plants as a result of the lower number of lesions and the longer incubation period. The incubation period (time from inoculation to lesion appearance) is highly correlated with the latent period (time from inoculation to appearance of sporulating lesions), which is an important factor for polycyclic diseases in determining the apparent infection rate (Parlevliet 1979). According to a blight monitoring program in Québec, late-sown carrots are sprayed the first time when a disease incidence of $50 \%$ is reached. Then at 7to 10-d intervals, fungicides are applied although it is not known if all these applications are necessary. Late-sown carrots are harvested at the end of 
September or in October. At that time, they are more than 13 wk-old and less susceptible to $C$. carotae than at the time of the first fungicide application. This indicates that applying fungicides in September may not be necessary but this should be verified by field experiments since this conclusion is based on a greenhouse experiment.

\section{ACKNOWLEDGEMENTS}

We gratefully thank Dr. Gaétan Bourgeois and Dr. Ajjamada Kushalappa for their help in writing the manuscript and to $\mathrm{Mr}$. Aimé Jacob for his technical assistance.

\section{REFERENCES}

Allen, S.J., J.F Brown and J.K. Kochman. 1983. The effects of leaf age, host growth stage, leaf injury and pollen on the infection of sunflower by Alternaria helianthi. Phytopathology 73: 896-898.

Arcelin, R., and A.C. Kushalappa. 1991. A survey of carrot diseases on muck soils in the southwestern part of Québec. Can. Plant. Dis. Surv. 71: 147-153.

Carisse, O. 1992. Effect of physical environment on Cercospora carotae and development of a model to predict Cercospora blight of carrot. Ph.D. Thesis. McGill University, Montréal $189 \mathrm{pp}$.

Carisse, O., and A.C. Kushalappa. 1989. Effect of media, $\mathrm{pH}$ and temperature on spore production and of inoculum concentration on number of lesions produced by Cercospora carotae. Phytoprotection 70: 119-124.

Carisse, O., and A.C. Kushalappa. 1990. Development of an infection model for Cercospora carotae on carrot based on temperature and leaf wetness duration. Phytopathology 80: 1233-1238.

Carisse, O., and A.C. Kushalappa. 1992. Influence of interrupted wet periods, relative humidity, and temperature on infection of carrots by Cercospora carotae. Phytopathology 82: 602-606.

C.P.V.Q. 1987. Guide de protection, légumes. Ministère de I'Agriculture, des Pêcheries et de I'Alimentation du Québec. AGDEX 250-605, $112 \mathrm{pp}$.

Eisensmith, S.P., T.M. Sjulin, A.L. Jones, and C.E. Cress. 1982. Effects of leaf age and inoculum concentration on infection of sour cherry by Coccomyces hiemalis. Phytopathology 72: 574-577.
Gottwald, T.R. 1985. Influence of temperature, leaf wetness period, leaf age and spore concentration on infection of pecan leaves by conidia of Cladosporium caryigenum. Phytopathology 75: 190-194.

Hooker, W.J. 1944. Comparative studies of two carrot leaf diseases. Phytopathology 34: 606-612.

Jennings, D.M., B.V. Ford-Lloyd, and G.M. Butler. 1990. Effect of plant age, leaf position and leaf segment on infection of leek by leek rust, Puccinia allii. Plant Pathol. 39: 591-597.

Jones, I.T., and J.D. Hayes. 1971. The effect of sowing date on adult plant resistance to Erysiphe graminis f.sp. avenae in oats. Ann. Appl. Biol. 68: 31-39.

Kushalappa, A.C., G. Boivin, and L. Brodeur. 1989. Forecasting incidence thresholds of Cercospora blight in carrots to initiate fungicide application. Plant Dis. 73: 979-983.

Ohm, H.W., and G.E. Shaner. 1976. Three components of slow leaf-rusting at different growth stages in wheat. Phytopathology 66: 1356-1360.

Parlevliet, J.E. 1979. Components of resistance that reduce the rate of epidemic development. Annu. Rev. Phytopathol. 17: 203222.

Populer, C. 1978. Changes in host susceptibility with time. Pages 239-262 in J.G. Horsfall and E.B. Cowling (eds.), Plant disease, an advanced treatise. Vol II. How disease develops in populations. Academic Press, New York. 436 pp.

Pretorius, Z.A., F.H.J. Rijkenberg, and R.D. Wilcoxson. 1988. Effects of growth stage, leaf position and temperature on adultplant resistance of wheat infected by Puccinia recondita f.sp. tritici. Plant Pathol. 37: 36-44.

Salisbury, F.B., and C.W. Ross. 1985. Plant physiology. H.Humphrey, ed. Wadsworth Publishing Company, Belmont, California. $540 \mathrm{pp}$.

SAS Institute Inc. 1987. Guide for personal computers. Version 6 edition. SAS Institute Inc., Cary, NC. 1028 pp.

Thomas, H.R. 1943. Cercospora blight of carrot. Phytopathology 33: 114-125.

Wetzstein, H.Y., and D. Sparks. 1983. Anatomical indices of cultivar and age-related scab resistance and susceptibility in pecan leaves. J. Am. Soc. Hortic. Sci. 108: 210218. 